\title{
Law and Literature and the Christian-humanist Educational Ideal in Hungary
}

\begin{abstract}
Politics and literature traditionally developed in a close contact with each other in Hungary. This paper argues that this intimacy had a particular reason: the fact that Latin educational ideals determined the way youth were brought up well into the 20th century. This had an impact on the way politics was understood here, including the fact that parliamentary debates were carried out in Latin well into the early 19th century.

And this had a further consequence as well: literature was not viewed simply as an autonomous field of activity, aiming only at aesthetic merits, but as a way to reflect on the fate of the nation. Lawyers had a professional training in rhetoric and therefore they had a familiarity with classical literature, which led many of them towards their own creative writing. And professional writers, too, had no other education than that of the Latin ChristianHumanist model, which made them representatives of the nation, as well as followers of earlier, classical patterns of writing. These features played a major role in the formation of the two heroes of the paper, the poets Dániel Berzsenyi and Ferenc Kölcsey, who had an internal conflict between each other, but who both embodied the type of late humanist political writers, so characteristic of the reform era of this region of Central Europe.
\end{abstract}

Keywords: Christian-humanist ideal, lawyers, Latin education, rhetoric, political writers, Dániel Berzsenyi, Ferenc Kölcsey, reform era

\section{19th-century Hungarian writers with a legal background-lawyers publishing fiction}

One of the key elements of Hungarian literature is that it is overloaded with politics, as memorably demonstrated by the competing views of two 20th century authors, Gyula Illyés and Péter Esterházy. While the former envisaged the Hungarian writer as thinking in terms of the people and the nation, according to the younger one the distinguishing feature of a writer was to think in terms of subject and predicate. These latter criteria do not make the Hungarian writer a homeless stranger, he claimed in one of his novels, and added that it was pointless as well as stylistically criticisable to use rhetorically charged sentences about your love of your home country.

The opposition between these two, contrasting self-perceptions of the function of literature did not turn out to be very fruitful, and it resulted in rather gloomy and tragic consequences in Hungarian politics in the 20th century. The barren debate on these issues took place under the pseudo-name of the populist-urbanist conflict. But it had at least one lasting conclusion: it called attention to the fact that while in the more fortunate part of the globe politics and literature got separated, here they are still closely connected.

If one looks for the reasons why the autonomy of literature was so hard to achieve in Hungary one should consider the traumas of national history (Tatars, Turks, Habsburgs, Russians, Trianon, the Holocaust, 1956) and the many sorts of sins, wrongdoings and cancelled choices which make 20th century Hungarian history such a hard reading. The answer to the above question is to be found somewhere among the balks of the breakdowns and other disasters of the political community.

* D.Sc., Associate Professor, Pázmány Péter Catholic University, Faculty of Humanities, H-2087 Piliscsaba, Egyetem u. 1.

E-mail: horcher@btk.ppke.hu 
To put it in a summary fashion, Hungary in the 19th century was very different from that of the 20th. It might be true, that urbanisation had its obstacles as well. But according to the hypothesis of this paper, the belatedness of Hungarian socio-political history left intact an even today very significant legacy among the changing circumstances of the early 19th century. The fact that in the first half of the given period most frequently writers were recruited from the law students is just one reason why literature remained interpreted within a wider cultural-social and political-context. What follows is meant to illustrate the thesis that if we want to understand why literature was very much a political issue in the first half of the 19th century, and why politicians were still so eager to shine with their literary virtues, we should not overlook the fact that the nobility which took part in public life had a Latin-based culture, which had been the determining factor in Hungarian public life for centuries. Even in the first decades of the 19th century Latin was regarded as the official language of parliamentary debates. This paper argues that the literate nobility had natural roots in the Christian-Humanist heritage which had an impact through both primary education built on Latin language, and the higher education of lawyers based on Roman law legal terminology. This lead to a situation where the mind frame of the middle ranks of the Hungarian estates was formed by a late version of humanist Latin.

In what follows I want to present the examples of two illustrious early 19th century authors, Dániel Berzsenyi and Ferenc Kölcsey, to propose that the Latin-based cultural substratum had a determining influence on the way of thought of literary gentleman, as far as both their legal and literary culture was concerned. They illustrate the extent to which legal professional qualification and literary "Bildung" suited each other, under the aegis of the Latin Christian-Humanist educational ideal. In the latter part of the paper I shall reconstruct some segments of this tradition they both cultivated, and which played a role in keeping together literature and law well into the 19th century.

\section{Berzsenyi and Kölcsey-two examples of the Latin-based culture of Hungary}

The debate between Berzsenyi and Kölcsey is one of the most interesting literary quarrels in the 19th century Hungarian cultural history. It is certainly grown out of mutual misunderstandings, and we shall not be able to clear up all that mess here. To judge the merits of the two sides' cause is even less our job. What makes their story interesting for us is to show that the two opponents belonged more or less to the same cultural climate, a fact that came to light only when Berzsenyi-after much preparation and delay-has published the piece in which he defended himself against the accusations of his 14 year younger colleague. In this piece he vindicated his concept of literature, his moral-Aesthetic system of thought. And yet, a latecomer would recognise that the two of them belonged to the very same intellectual tradition. In order to make that recognition easier, we are not going to concentrate on the differences of the two authors. It seems more important to show the common cultural ground under their feet. It is worth considering why these two poets were so keen to defend political liberty in their literary texts.

To draw the outlines of an answer to these questions, let us begin to deal with Berzsenyi. He received that upbringing of the Lutheran gentry, which kept the protestant ideal of Hungarian liberty in its focus, up to the beginning of the early Reform Era. ${ }^{1}$ The

1 "...that kind of urbanised gentry, whose intellectual horizon was determined by their lutheran upbringing, and by their need for culture. This way of life has been for long characteristic of the 
poet attended the Liceum in Sopron, an institution which was established in the middle of the 16th century, in the fresh fever of reformation. As we shall see, the educational programme of the school determined in many respects the way of thinking and writing of its most famous student. Although the impatient and non-sociable youngster gave up his learning before matriculation, the nation- and knowledge-ideal of the school, inspired by ancient Roman historical narratives, did have a lasting influence on his poetic outlook.

Kölcsey, on the other hand, was born into a gentry family with a Calvinist leaning, and was brought up in Debrecen, nicknamed in those years as the Calvinist Rome. Although it is well known that the poet-politician remained in conflict with his school, and with the provincialism embodied by it, and in spite of the fact that he turned out to be one of the proponents of reforming feudal Hungary, even his poetic vision is to be interpreted in the context of the nobleman's republic inspired by antique models.

To compare Berzsenyi's and Kölcsey's views of the role of literature in the nation's life in what follows I sum up the line of arguments of one of their respective works. In Berzsenyi's case it is going to be his "Poétai harmonistica" (A Theory of Poetical Harmony), a theoretical work written in a Platonic vein as an academic inaugural speech in 1833. My interpretative approach will be based on the primary research of Lajos Csetri and Ágnes Bécsy. In Kölcsey’s case, I take a short piece, entitled: Iskola és világ (School and world), which was written as an epistola in 1815 , and published in $1826 .{ }^{2}$

Ágnes Bécsy interprets Berzsenyi's efforts in this late theoretical piece with the help of an earlier letter by him, stating: "I look at the Aesthetician... not only as a florist, like Kazinczy, but as in all respects the main defender of culture. Because of this, I cannot and do not want to separate the beautiful from the useful, and because of this, I made the job of my old age to defend our poesy from the harmful floristic ornaments, affectations, artificiality, and from drowning into music." 3 From this quote, I would argue, one can see that Berzsenyi's aim is to show why poetry-or art in general-is not as autonomous as Kant and his followers would like it to be, and following the footpath of neokantianism and Romanticism modern Aesthetics claims it to be. Berzsenyi's main reason for his understanding of the term is that he does not want to see poetry as a feminine and sentimental attitude to the world, as it is stylized by sentimentalism. Berzsenyi finds the role of the critic also more than simply expressing the inner emotions brought out by a work of art: "... it is not enough to criticize the work in itself, but you have to be able to criticize it from the most important point of view, from where the question is: how does the whole work fit together with the aims of the nation and humanity and with the philosophy of the whole of culture". ${ }^{4}$ The reason behind the birth of a work of art is not simply to raise emotions, but to serve the aims of the nation-which seems to be in harmony with those of humanity in his philosophy of culture, in which the Roman inheritance remains a strong component of the order of values. A further aim of poetry is to train humans, and more particularly, to train the human spirit. According to Bécsy, it is here that the Platonic concept

evangelical "intellectuals". The context was very nicely drawn by László Németh in his Berzsenyibook and in his essays on the great poet." Thimár, A.: Hol maradt el Berzsenyi? [Where did Berzsenyi fall away?] Kortárs, 52 (2008) 9, 68-77. http://www.kortarsonline.hu/0809/thimar.htm (All translations mine, unless indicated.)

${ }^{2}$ In: Kölcsey, F.: Erkölcsi beszédek és irások [Moral speeches and writings]. Publ. by Csaba O. Budapest, 2008. 9-10.

3 Letter to Döbrentei, June 4, 1828.

${ }^{4}$ Quoted by Bécsy, Á: Berzsenyi Dániel [Daniel Berzsenyi]. Budapest, 2001. 97. 
of "éros" re-emerges in an old-new garment: "this tradition has been married in the retort of European Neohumanism with the Christian tradition". 5 This eros, which has its humanistic-educational function, raises man to follow "the harmonic middle" ("harmoniás közép"), a model, in which human spirit, responsive to beauty, is in connection with the morally good, itself supported by the ethics of the New Testament.

In connection with the educational and spiritually motivating functions of poetry Bécsy reminds us that the late Berzsenyi held in high esteem the moral thought of Michel Montaigne. ${ }^{6}$ I take this fact as a sign that whenever Berzsenyi thinks along ancient patterns, about the educational and nation-sustaining capacity of the concept of taste, he must be moving within the framework of those Christian (and neo-pagan) humanist ideals.

Bécsy herself refers to Lajos Csetri's Berzsenyi analyses, which in an exemplary fashion showed other sources from which Berzsenyi's classical Bildung-conception might stem. Csetri adds to the list of the names of Horace and Plutarch the writers of German neoclassicism. Their texts are claimed by him to have established the antique ideal of the young Berzsenyi, that neoplatonic Hellenism, which was shared by Winckelmann and other late 18th century representatives of German neoclassicism: "his whole Greekness can be traced back to the German spiritual life of his age, his Greekness is the Hellenism of Winckelmann, of German neohumanism and the 'hellenism' of German classicism". ${ }^{7}$ Csetri also emphasizes that this is a pre-Kantian German influence, a mode of thinking in which ethics and aesthetics is closely connected-and here he discovers a further dimension of a strong English impact: "...practical English philosophy of $\operatorname{life}^{8}$, which in its more democratic context can realize more of the nature of Greek "phronesis", does never excommunicate rhetoric, the mediator of the two thousand years old tradition of the philosophy of life and its ideal of the human being". ${ }^{9}$ This English substratum is regarded as a counter current within German classicism by Csetri, and he connects it to the name of Herder, Jean Paul and Bouterwek. He claims that Berzsenyi is supported by this tradition, when he writes that human(e) education, meant in the most general terms, or "real poetry is a beautiful religion", and "its aim is not simply emotional, intellectual and imaginative perfection, but it has to be supported on the second level by moral greatness, and on the third level by the divine majesty and by the happy calmness of religion". ${ }^{10}$

Now let us see, how Berzsenyi's debating partner, Kölcsey speaks about the problem of Bildung, or of the meaning of the original ancient Greek concept of poesis? Of the possible forms of knowledge he picks out four in the text we analyse: "fine arts" ("szép mesterségeket"), "human studies" ("Humanisticum"), "Mathematics" ("Mathésis") and "Metaphysics". Of these he shows as exceptionally relevant the man who lives in the fine arts, as "Grace connects itself to him". He contrasts the ancients, in other words the great

5 Bécsy: op. cit. 104.

6 "According to references in his letters and theoretical works, a great reading experience of his long sunset was a crumpled volume, which was saved in his library: Mihály Montaigne's ideas of different subjects, by Nagy Tóth József, 1803" Bécsy: op. cit. 216.

7 Csetri, L.: Nem sokaság, hanem lélek. Berzsenyi-tanulmányok [This is not crowd, but spirit. Studies on Berzsenyi]. Budapest, 1986. 377.

8 This is the English equivalent of the German term of "Lebensphilosophie".

9 Csetri: op. cit. 378. At another point, he mentions that Berzsenyi made extensive notes of his readings of the Aesthetic works by Home, Schiller, Bouterwek, Batteux, Jan Paul and Luden. Ibid. 382.

10 Ibid. 384. 
Greeks and some Romans with those who rule today, and he regards the former as belonging to the "happy skies". In their circle "the feeling for the beautiful" was paired with the wisdom of a matured age, that is why they could become lovable philosophers and soldiers, and "non-effeminate poets". The effeminate poet of modernity is a victim of "sensibility and speculation", while the ancients were formed by practice: "Actions, and public performance form a useful man, who, if he carries in his heart the seeds of the beautiful, will turn into Pászthori, Ürményi”.

As one can read in the notes to the modern edition, Pászthori, Ürményi refer to two contemporaries. Sándor Pászthori was "a legal scholar, governor of Fiume (Rijeka), appointed by Joseph II as the referent administrator of the Hungarian Schools". József Ürményi was “ 'országbíró’ (Judex Curiae Regiae). He created Ratio Educationis (1777).” This means that both lawyers excelled as reformers of the Hungarian school system. ${ }^{11}$

The short text of Kölcsey is a proof that for him, too, poetry preserved its antique Greek connotations. That is why "poesis" (according to its original meaning: creating) is connected to activity (praxis). It is not accidental that Kölcsey refers to the humaniores-his conception is also tied to the humanistic ideal of education. Before, however, we turn towards this ideal of human(e) education, we have to consider shortly the nobility's ideal of the state, which was also inspired by antique role-models.

\section{The ideal of the state of the Hungarian noble republic ${ }^{12}-$ as an idealised version of the antique polis and the Roman republic}

If we try to understand how the learned and educated ${ }^{13}$ nobility turned towards the problems of the country, first we have to reconstruct the language which was available for them to conceptualise their experiences. Naturally I do not mean that the artificial reformation of the language accomplished by the generation of the turn of the 18-19th century would be responsible for the schism between our political vocabulary and the political ideas of the early reformers. Rather, I claim that the patterns and patents of political thought and speech available in the age, were closely connected to those historically embedded moral elements of culture, which had been transmitted in the schools of the age, also in connection with the teaching of Latin, since the reformation, generation after generation. József Takáts, in a writing in which he reconstructs the political languages of the age, talks about the republican discourse ${ }^{14}$-the way of speaking which is identified by Csetri with the language of the young Berzsenyi's "Spartan type of plutarchism". This way of thought was introduced and first explained in Plutarch's Parallel lives, contrasting it with that of the Athenians, aimed at the all-round, bodily-cum-spiritual self-development. In Csetri's narrative Berzsenyi starts

11 In the original version József Dessewffy was mentioned instead of Ürményi. He was one of the founders of the Hungarian Academy of Sciences and a translator of Cicero.

12 I take this term from the Polish ideal of Noble Republic, Nobles' Democracy or Nobles' Commonwealth (Polish: Rzeczpospolita Szlachecka).

13 These two terms are not simply synonyms, but rather complement each other in the usage of the age.

14 Takáts, J.: Magyar politikai beszédmódok a XIX. század elején. A keret [Hungarian political discourses at the beginning of the 19th century. The framework]. In: Szajbély, M. (ed.): Mesterek, tanitványok. Ünnepi tanulmánykötet a hetvenéves Csetri Lajos tiszteletére [Masters, followers. Studies dedicated to the 70 years old Lajos Csetri]. Budapest, 1999. 224-248. 
out from a Spartan starting point and arrives at the Athenian paradigm at the end. That is, starting from the cult of physical exercise, and the purity of the soul and the body he arrives step by step at the Athenian ideal of the perfection of the human spirit. It is again the AngloSaxon orientation that leads him in that direction, because "this Athenian humanistic ideal built on 'kalokagathia' will be the foundation of the gentleman-ideal of the English Enlightenment and through the Göttingen neohumanism of the German literary classicism and early Romanticism". ${ }^{15}$

Yet Takáts also refers to another type of discourse, which he distinguishes from this republican discourse: and the second type is the discourse of the ancient constitution. In this version of the famous Pocockean theme, ${ }^{16}$ Takáts uses the earlier results of László Péter, Béla Németh G. and Miklós Szabó, claiming that the Hungarian version of patrician liberalism resembles "the classic Anglo-Saxon type". This constitutional thinking is not born in the age of written constitutions, but is based on earlier traditions of statesmanship. Analysing a text by poet Sándor Kisfaludy, Takáts characterises this discourse the following way: "According to this interpretation, the constitution has been in existence for 900 or 1000 years, it is unchanged in its basic principles, as the common creation of the nation and its prince. The nation in this political language means the community of citizens participating in government: it means the nobility". ${ }^{17}$ Beside Kisfaludy, Takáts can show up the scheme of ancient constitution in the texts by Kölcsey, as well, mainly in his county assembly speeches.

It is even more interesting that, as Takáts points out, the reference to the ancient constitution is often linked to the republican language. ${ }^{18}$ This rhetorical combination can be traced back at least to Cicero, who, as the last great ideologue of the Roman republic, taught, in accordance with Roman habits, the wisdom of the forefathers and the honour of accepted manners. It is, therefore, not accidental, that Takáts, too, accentuates the Latinhumanist educational ideal, which is present in the contemporary Hungarian schools: "it is easy to answer the question where did Berzsenyi learn this republican language: from the middle of the 16th century up to the end of the 18th century the reading lists in the curriculum of the gymnasium classes included beside the Latin authors Sallust, Livy, and Cicero's De officiis. Their works are the most frequently mentioned classical sources of the republican discourse". ${ }^{19}$

The Spartan and/or Athenean republican discourse, transmitted by Roman sources, and the language of the ancient constitution are both easily available to the early modern Hungarian nobles turned into lawyers and writers, when they draw the outlines of the patrician ideal of the nation and the state. The substance of their culture consisted of narratives taken from Latin (and Greek) authors and historians, and this predestined them to return to the language of neo-classicism. But the same direction was pointed at by their legal practice as well, which was based on the Tripartitum by Werböczy, prescribing the privileges of the Hungarian nobility on a customary law basis. Werbőczy, who was educated

15 Csetri: op. cit. 64.

16 Pocock, J. G. A.: Ancient Constitution and the Feudal Law. Cambridge, 1957.

17 Takáts: op. cit. 229.

18 Ibid. 230.

19 Cicero, in the second book of his The Republic lets "old Cato" claim that "Our constitution... had been established not by one man's ability but by that of many, not in the course of one man's life but over several ages and generations." The Republic, book 2, 1. I used the following edition: Cicero: The Republic and the Laws. Transl. by Niall Rudd. Oxford, 1998. 35. 
at the university of Kraków, was a kind of humanist himself, reading both Latin and Greek. Although he sharply opposed the reformation, his Tripartitum served as the ideological basis for the nobility's struggle to defend their independence. This law book soon turned into a historical-constitutional reference-point. It was used as a guide for political orators to preserve that Nobles' Commonwealth, which was itself based on Roman precedents.

\section{Linguistic-rhetorical education, and the role of rhetoric in early 19th century culture}

Above I tried to reconstruct how our two heroes thought of their own poetic activity, and how it was connected to an idealised vision of education, which was claimed to bring perfection not only to the individual, but also to the nation. We have shown, that poetry for them was not a l'art pour l'art activity, but a part of the humanistic programme of human fulfilment, not the expression of an individual passion simply, but a service for the political community, a kind of cultural religion. We have seen the antique sources of these ideas, and that the self-concept of the patrician nation is also derived from those sources, although transformed by the local tradition of post-reformation Latin teaching established as part of the humanistic heritage. Now let us turn to the concept of rhetoric as understood within this framework of humanist education. The claim, here, is that this rhetoric served as a natural mediator between our heroes' literary-aesthetic and lawyer-politician ways of thinking and writing.

The antique heritage was taken over in Renaissance Europe in the context of lively debates on Christian religion. Christian humanism took human self-fulfilment as its most important target. Already Pico della Mirandola's, or even Petrarca's writings outlined an ideal, based on antique sources, which saw the potential for this worldly human fulfilment in culture, in the cultivation of the human mind and spirit. ${ }^{20}$ Hans-Georg Gadamer nicely sums up in a comfortable way those terms, which played a major role in the human mission of realizing our potentials through culture. ${ }^{21}$ Through the categories of Bildung (culture), "sensus communis", judgement and taste Gadamer successfully reconstructs a vocabulary which proves that humanism-both in its Aristotelian, Neoplatonic or simply Christian version-was stronger philosophically than those historians of ideas claim, who take as the early modern lingua franca the new philosophy based on the fresh natural sciences, like the teachings of Descartes and Kant. Christian humanism turns out to be definitely more than simple rhetoric. And yet Gadamer also stresses that rhetoric has a major role in this tradition, even if the humanist programme of rhetoric was soon overtaken by hermeneutics, as a result of the spread of literacy and of the printed word. Yet for him, hermeneutics is not simple philology, but keeps its organic relationship with practical philosophy: the written word is connected to action, and its message is not simply of epistemological interest, but has

20 Words like culture and cultivation became frequently used only in the 18th century, following ciceronian-humanist patterns. About the historical development in the background, see the classical work of Joseph Niedermann. Niedermann, J.: Kultur: Werden und Wandlungen des Begriffs und seiner Ersatzbegriffe von Cicero bis Herder. Florence, 1941.

21 The guiding concepts of humanism, In: Gadamer, H-G.: Truth and Method. Transl. Rev. by Joel Weinsheimer and Donald G. Marshall. London-New York, 1975, 1989. 1.1.1. B., 8-36. 
relevance in one's daily life, and therefore it is connected to the question of individual and communal fulfilment. ${ }^{22}$

In the writings and deeds of its best representatives, the Hungarian reform age connects its national programme of cultivation (meant as the education of the spirit) to a kind of practical philosophy, the vita contemplativa to the vita activa. Gadamer's philosophical hermeneutics helps to reconstruct the key concepts of the rhetorical tradition, including the principle that each item of communication is itself an (inter)action. Kölcsey is one of the best examples of the literary gentleman who does not refrain from political action, or of the statesman who is able to express himself in the world of ideas as well. Perhaps the key to the formation of this type of mind is the practice of being a lawyer, educated in the Roman model. The concept of law which has been preserved in Hungary for centuries guaranteed that the lawyer was practically oriented, learning his job by imitating the example of more experienced colleagues, and in the same time was historically or even also literally cultivated and well-versed, to be able to perform his role as a public orator. In the political and legal practice of the country, political and legal actors were expected to follow the role model of the cultivated, sociable humanist intellectual. ${ }^{23}$ The political situation, generally conceived in Hungary as being under the yoke of foreign despotism, and the traditional way of practicing politics in the county assemblies, both contributed to the continuing relevance of rhetoric and the public persona of the rhetor. This conclusion was also reasserted by the lively communities of protestants in the country who were trained in oral and written disputations. The teaching of the orator's skills in legal education remained important and according to the stylistic conventions of contemporary literature being rhetorically polished was a first requirement-it will remain the standard until Petöfi arrives on the scene, who transforms literary diction by denying the legitimacy of high flying, sublime rhetoric and preaching a poetics of honesty and the language of ordinary men.

My claim is, therefore, that until Petöfi, both literature and law as a linguistic art was interpreted within the context of eloquence. Neither the lawyer's, nor the literary writer's activity was easily separable from forms of morally or politically relevant practices. The ideal form of education cherished by the humanists was not the way towards professionalism, or the working out of separate individual systems of rules for each discipline or skill. Instead, it promulgated an ideal of cultivation, based partly on the scholastic concept of potentiality, itself relying on certain Aristotelian insights, according to which one, as the creation of God, was called to exploit the most of his/her inner, still latent, and sleeping abilities, and to do it as radically as one could. Even more interestingly, these capacities were to be activated not by theoretical knowledge but in practice, empirically, in accordance, with the living tradition of the given form of activity. ${ }^{24}$ And these capacities could strengthen

22 A similar description of humanist thought is provided by Ernesto Grassi, see Grassi, E.: Rhetoric as Philosophy. The Humanist Tradition. University Park (Pennsylvania)-London, 1980.

23 An ideal, which Gadamer traced back to that of the courtier, as created by Castiglione and Balthasar Gracián, and even to earlier traditions of the heroic virtues of antiquity, and also relying on Christian virtues.

${ }^{24}$ For a relevant theory of practices within a community, see A. MacIntyre's After Virtue, claiming: "By a practice I am going to mean any coherent and complex form of socially established co-operative human activity through which goods internal to that form of activity are realised in the course of trying to achieve those standards of excellence which are appropriate to, and partially definitive of, that form of activity, with the result that human powers to achieve excellence, and human conceptions of the ends and goods involved, are systematically extended". MacIntyre, A.: After Virtue. London, 1985. 187. 
each other in each individual's own practical economy, and contribute to the emergence of a general sense, which was perhaps the most important fruit of self-development: the ability to choose wisely, which was synonymous with taste or practical wisdom in this discourse.

Through taste the individual acquired a direct insight into the value system of his community, but not in an abstract, universalisable format, but as applied in concrete, this wordly emergency situations. Each occasion, when the individual could operate his/her taste, contributes to the further refinement of the personality, and on the long run this enabled the individual to develop even further, learning also one's self better and better. In the humanist ideal, therefore, both literary and legal activity found its final raison d'être in the life long learning process in the school of self-cultivation. ${ }^{25}$

The fact that both law and literature-as an oral art-was to be performed like eloquence lead to a situation where reflections on the inner dynamism and surprising mechanics of living language become ever more relevant. It is therefore logical, that the inheritors of German neo-classicism, who were inspired by the humanist heritage, paid particular attention to the nature and workings of language. The same is true about the Hungarian Reform age: an obvious sign of the refined linguistic reflectivity of the age is called in Hungarian intellectual history the "age of neology", with a language theoretical debate between neologs and traditionalists. Ironically, it is exactly this very same linguistic selfawareness which led to a new born interest in the primacy of the native language both in education, in legal practice and in political debates that has a disastrous effect on the keeping up of the Latin Humanist model. In Hungary, by the 1830s a new generation stepped up on the stage of public life and with them the Reform age was taking over another great intellectual inspiration-that of the Romantic movement-both in literature and in political thought.

\section{Summary}

This paper tried to answer the question how to explain the fact that the language of law and that of literature had an interface in the Hungarian Reform Age of the first half of the 19th century. What was the reason behind the fact that there was an overlap between the circles of writers and lawyers, that a number of writers were educated and even practiced as lawyers, and that lawyers tried themselves as writers, as well. The paper argued that the concept of literature which governed the early Reform Age was deeply embedded into the humanist tradition, which was supported by the widespread teaching of Latin, transmitting elements of antique culture and narratives of ancient history, presented as part and parcel of native culture. Humanist tradition also preserved a rhetorical practice for this period, which was opposed to the specialised languages of professional science in the early modern era, and provided a framework for understanding literature as part of a more general social normative system of personal virtue and decorum. Grassi and Gadamer provides a framework of interpretation in which a rhetorical humanism is opposed to a science based philosophical rationalism, as two competing systems of knowledge, or episteme in Foucault's sense of the word, within the early modern context.

25 The idea of a practice or tradition acquired by the individual as part of one's self-cultivation was introduced by Pierre Hadot. See: Hadot, P.: Philosophy as a Way of Life Spiritual Exercises from Socrates to Foucault. Oxford, 1995. Hadot had a huge impact on the late, although differently tuned philosophy of Michel Foucault. 
As examples of the overlap between literary and legal forms of culture I presented Dániel Berzsenyi and Ferenc Kölcsey, two early 19th-century poets who were schooled in the manner characteristic of the middle ranks of the nobility in the protestant territories of Hungary, and this way acquired a culture, which looked at literature as a public activity, with very definite moral and political functions, and which encouraged its subjects to complement even their legal and political rhetoric with a literary-artistic ambition. I claimed that there was a common ground between the two fields of activity, which enabled practitioners to commute between the two genres.

The humanist heritage could survive for a long time in Hungary, which, however, is not to be taken simply as a sign of Eastern-European provincialism, although the element of belatedness is very much there in the phenomenon. If the literary-cum-legal culture which was inherited from Latin-Christian humanism, prevailed in the first third of the 19th century and was nicely complemented by a robust political discourse of republican type ancient constitutionalism, it is the result of local-political, legal and theological-culture, which created new, unprecedented cultural configurations and often presented quite remarkable achievements. The cohabitation of the lawyer and the writer was one of the governing forces behind the emergence of a Reform Age in the political and cultural history of Hungary, behind the Age of Neology in the history of Hungarian as a native language. It had, though, a special effect on Hungarian literature, which on the long run has proven disadvantageous: a debate between "Nationalists" and "cosmopolitans". This afterlife of the phenomenon gives a special flavour to this tradition of the lawyer writers, unparalleled by other national literatures, except, perhaps, the Polish one. 